\title{
Orientations to the Development of Vietnam's Supporting Industries between 2015 and 2020
}

\author{
NGUYEN TRONG HOAI \\ University of Economics HCMC - hoaianh@ueh.edu.vn \\ HUYNH THANH DIEN
}

28. CORPORATION (Agtex. Corp.) - thanhdien82@yahoo.com

\begin{abstract}
ARTICLE INFO
ABSTRACT

Article history:

Inheriting extensive experience of foreign countries together with

Received: secondary data adopted in a qualitative research study, this paper

Dec. 27. 2014 addresses the orientations and solutions to the development of Vietnam's supporting industries (SIs) between 2015 and 2020. Apart Received in revised form: from identifying barriers to and/or limitations of policies on their development, the findings pinpoint five SIs worthy of notice for

Mar. 23. 2015

Accepted: mechanical appliances, plastics and rubber, electrical/electronic equipment, textile and garment, and leather and footwear. To drive

Jun. 28. 2015 these along their right track, priority should be given to consolidating the organization in support of SIs' development, cultivating support for premises and access to attractive markets, and transferring Keywords: technological advancement that enhances competitiveness of firms in the field.
\end{abstract}

supporting industries, industrialization. 


\section{Introduction}

An objective set for Vietnam during its process of industrialization until 2020 is to basically become a modern industrialized country. However, the development of national industries increasingly exposes many shortcomings, especially no success in eliminating overdependence on imported input materials and foreign-provided auxiliary products. Many causes contribute to the problems thereof, whose roots may partially be some of the SIs' drawbacks; thus, it is necessary for certain research to put forward orientations and concrete measures for SIs' development. In this context this study comprises three main steps: initially, an overview of activities and necessary conditions for the development of SIs; next, on its basis, the analysis of their performance in order to identify the barriers to and shortcomings of Vietnam's policies; and last, the orientations and solutions to promote these industries' development.

\section{Structure of SIs and conditions for their development}

Pursuant to the Prime Minister's Decision No.12/2011/QD-TTg on policies on development of Vietnam supporting industries, SIs include those which supply materials, appliances, components, and fittings for the finished product manufacturing and assembling industry. According to this definition, the value chain related to SIs is as prescribed in Figure 1, and the analyses are also based on the analytical framework of this figure, consisting of two main groups regarding SIs. 


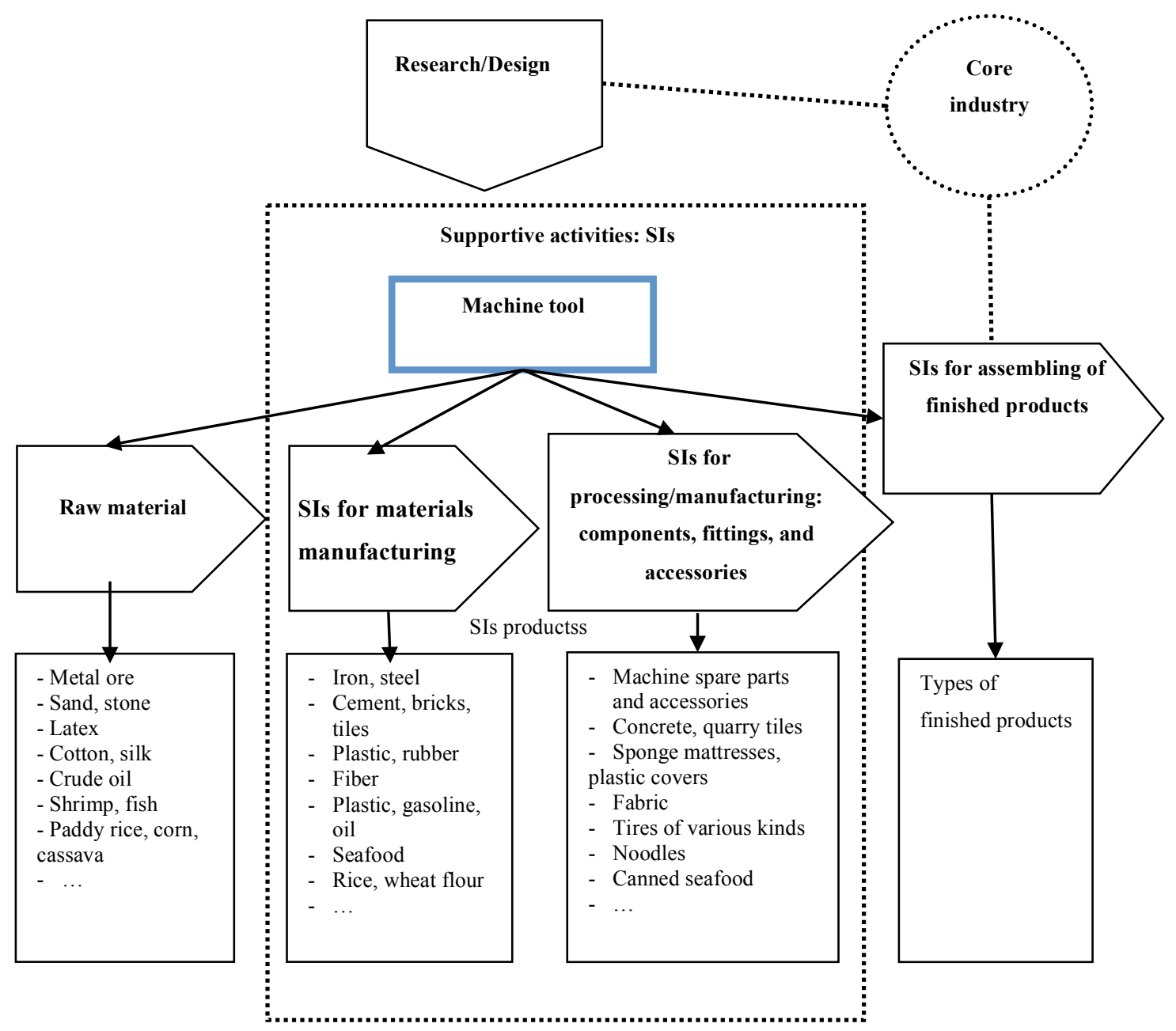

Figure 1. Identification of SIs in the chain of industrial activities

Source: Authors' generalization based on a brief overview of the theories

Foreign experience of industrialization has shown that SI group is not the starting point for or precursor to the development of other industries, but these others' growth does entail SIs promotion based on the government's suitable regulatory policies. The process of industrialization typically targets basic industries, gradually forming two main branches of the industry sector, including "core" and "supporting" industrial activities. The mechanical industry, as in Japan in the 1940s, during its rapid development, required from Japanese mechanical enterprises in-depth specialization in 
producing complete products along their cost minimization. When these criteria were fulfilled, the demand for their mechanical appliances started to rise, which became a motive for SMEs' participation and marked the beginning of newly born SIs for mechanical appliances (Ministry of Economy, Trade, and Industry, 2003). Unlike Japan, in recent decades, there has existed a linkage between SIs in such countries with newly developed SIs as Korea, Thailand, and Malaysia, and other industries in which FDI sector joins. Through coherent policies on promoting cooperation between domestic and FDI businesses these countries' governments have enjoyed moderate success in attracting and guiding the FDI firms, boosting the growth of the national SIs.

The above arguments indicate that three conditions for the attraction of enterprises' participation in SIs basically depend on the demand from large enterprises in the "core" stages of industries. First (C1), to encourage local firms to invest technologies in manufacturing supporting products, government should drive the finished product assembling and manufacturing industries to the product design and define local supply of SI products. Second (C2), to increase demands from both domestic and foreign customers for the products produced by local firms, domestic technologies for machine tool manufacturing, in their healthy development, should be able to reduce technological investment costs as well as business risks and enhancing the competitiveness in SIs production. Last (C3), to hold attention of enterprises in designing and manufacturing finished products, the local SIs enterprises themselves must satisfy the demands from these enterprises and step by step take part in global value chains. Among the three conditions, the crux of the matter lies in the second one, also called technological condition because it not only stimulates the suppliers of SIs' products (in the way it helps local SMEs meet technological requirements to take part in the final-product value chains) but also satisfies the demands for SIs' products from local and foreign enterprises. Model of conditions for SIs' development can be generalized in Figure 2 below. 


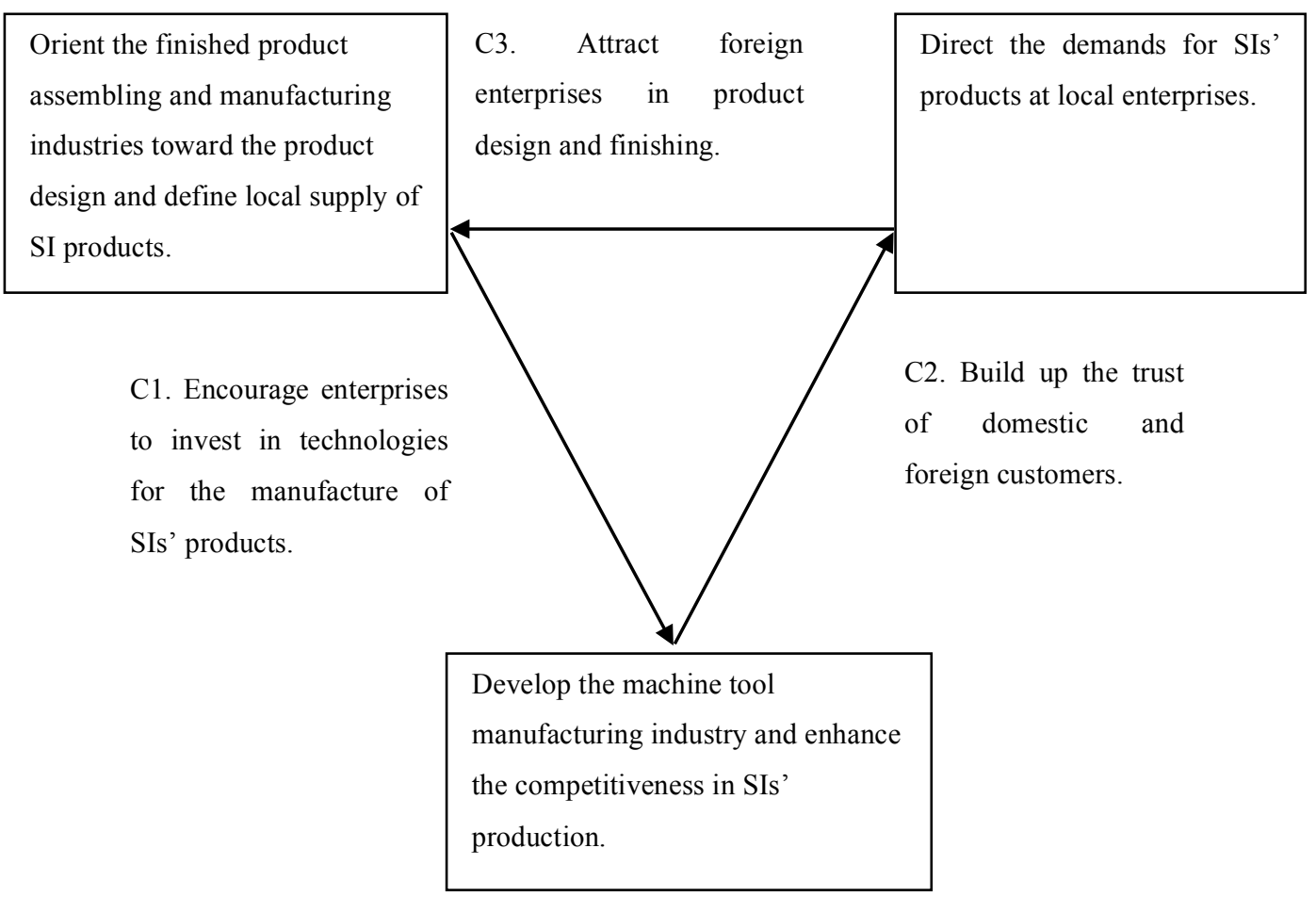

Figure 2. Model of conditions for the national SIs' development

Source: Authors' generalization based on a brief overview of the theories

\section{Data and research methods}

To propose orientations and solutions to the SIs' development, the study investigates the current structure of the industries, from the sources of input supply and SIs' product supply to the production of finished products of the six key SIs, whose production value accounts for over $50 \%$ of that of the nation as a whole. Analyses of the data, mostly secondary data collected from GSO, are carried out to describe the activity structure for every stage of the industries. In addition, a qualitative survey, conducted at some typical enterprises categorized into distinctive SIs, aims at assessing the product supply on the basis of the 2014 SI development project in HCMC. With the barriers further looked upon, the research defines the orientations and solutions to the Vietnamese SIs' development. 


\section{Realities of Vietnam's SIs}

\subsection{Material supply for SIs' production}

Blessed with favorable natural conditions Vietnam gains many advantages in raw material supply for its SIs, such as metal of different kinds, latex, crude oil, and raw agricultural products. Up to 2014 the proportions of agriculture, forestry, and fishing accounted for $18 \%$ of GDP, whereas $11.49 \%$ of GDP was attributed to mineral exploitation (Table 1).

\section{Table 1}

Sectoral distribution of agriculture, forestry, fishing, and mineral exploitation to GDP

\begin{tabular}{lccccc}
\multicolumn{1}{c}{ Year } & 2005 & 2007 & 2009 & 2011 & 2013 \\
\hline Agriculture, forestry, and fishing & 19.30 & 18.66 & 19.17 & 20.08 & 18.38 \\
Mineral exploitation & 9.73 & 8.96 & 9.14 & 10.34 & 11.49 \\
\hline
\end{tabular}

Source: GSO (2014)

Table 2 shows that in spite of large increase in imports, raw materials are less used in processing SIs' products, but instead are simply processed and exported as primary products. For instance, regarding the growth or reduction in major leading exports/imports in 2014 compared to 2013, there was a vast increase in the import of iron and steel while the exported steel-based products fell quite sharply. Even though export of textile and garment enjoyed an increase, the rate of import of fabric of various kinds grew correspondingly. In addition, the growth rate of import of textile and garment/leather and footwear materials and accessories was twice as much as that of export of footwear, and was approximately equal to that of export of textile and garment. 


\section{Table 2}

Rates of increase/decrease in Vietnam major exports/ imports in 2014 compared to 2013

\begin{tabular}{|c|c|c|c|}
\hline \multicolumn{2}{|c|}{ Export } & \multicolumn{2}{|c|}{ Import } \\
\hline Major products & $\begin{array}{c}\text { Increase }(+) / \text { Decrease } \\
(-)(*)\end{array}$ & Major products & $\begin{array}{c}\text { Increase }(+) / \text { Decrease } \\
(-)(*)\end{array}$ \\
\hline $\begin{array}{l}\text { Computers, electronic } \\
\text { products and appliances }\end{array}$ & $-11.5 \%$ & $\begin{array}{l}\text { Machinery and } \\
\text { equipment }\end{array}$ & $+26.2 \%$ \\
\hline Steel-based products & $-19.7 \%$ & $\begin{array}{l}\text { Iron and steel of } \\
\text { various kinds }\end{array}$ & $+51.0 \%$ \\
\hline Textile and garment & $+13.5 \%$ & $\begin{array}{l}\text { Fabric of various } \\
\text { kinds }\end{array}$ & $+12.3 \%$ \\
\hline Footwear & $+6.4 \%$ & $\begin{array}{l}\text { Textile and } \\
\text { garment/leather and } \\
\text { footwear materials } \\
\text { and accessories }\end{array}$ & $+13.5 \%$ \\
\hline $\begin{array}{l}\text { Wood and wooden } \\
\text { products }\end{array}$ & $+22.1 \%$ & Plastic materials & $+8.2 \%$ \\
\hline $\begin{array}{l}\text { Handbags, wallets, } \\
\text { suitcases, hats, and } \\
\text { umbrellas }\end{array}$ & $+15.3 \%$ & Chemicals & $+8.2 \%$ \\
\hline
\end{tabular}

Note: $(*)$ denotes increase (decrease) in 2014 compared to 2013

Source: Calculations based on data from GDVC (2014)

One more important point is the very high growth rate of import of machinery and equipment. Owing to major restrictions on its machine tool and appliances manufacturing technologies, Vietnam must import a large number of industrial materials, such as iron and steel, fabric, textile and garment/leather and footwear materials and accessories, etc. (Table 2). This shortcoming also results in the dependence on foreign suppliers; therefore, the ratio of imported machinery and equipment has reached quite a high level for many years, accounting for $37 \%$ of total import turnover while this figure for fuels, raw materials was over 55\% (Table 3). The limited technology, as was affirmed in the previous section, is the main barrier to attracting domestic enterprises' contribution to SIs' development. 


\section{Table 3}

Vietnam's import of industrial materials

\begin{tabular}{lcccc}
\hline Year & 2008 & 2010 & 2012 & 2014 (estimated) \\
\hline Value (USD million): & & & & \\
- Machinery, equipment, appliances & $22,566.7$ & $25,152.4$ & $39,911.6$ & $58,853.6$ \\
- Fuels, raw materials & $49,149.1$ & $50,343.6$ & $63,518.6$ & $83,837.3$ \\
Ratio as percentage of total import turnover & & & & \\
- Machinery, equipment, appliances & 28.0 & 29.6 & 35.1 & 37.1 \\
- Fuels, raw materials & 60.8 & 59.4 & 55.8 & 55.4 \\
\hline
\end{tabular}

Source: GSO (2014) and GDVC (2014)

\subsection{Realities of SIs' product manufacturing}

Firms operating in SIs have primarily been dedicated to the processes featuring simple technology, low added value, and thereby restricted participation in global value chains. Industrial output value of core industries accounts for $50 \%$ and $45 \%$ of manufacturing output and the whole industrial sector, respectively (as of 2013) (Table 4).

\section{Table 4}

Industrial output value of a few core industries in Vietnam by percentage (\%)

\begin{tabular}{|c|c|c|c|c|c|c|c|c|c|}
\hline Year & 2005 & 2006 & 2007 & 2008 & 2009 & 2010 & 2011 & 2012 & 2013 \\
\hline Textile and garment & 8.0 & 8.9 & 8.7 & 8.2 & 8.1 & 8.0 & 8.2 & 7.4 & 6.9 \\
\hline Leather and footwear & 4.3 & 4.0 & 3.8 & 3.7 & 3.2 & 3.4 & 3.4 & 3.3 & 3.2 \\
\hline $\begin{array}{l}\text { Manufacture of rubber } \\
\text { and plastic products }\end{array}$ & 3.9 & 4.1 & 4.1 & 4.4 & 4.3 & 4.4 & 4.4 & 4.0 & 3.7 \\
\hline Mechanical engineering & 9.56 & 9.8 & 10.63 & 10.95 & 10.45 & 11.51 & 10.73 & 10.74 & 10.75 \\
\hline $\begin{array}{l}\text { Electrical/electronic } \\
\text { appliances }\end{array}$ & 6.96 & 7.09 & 8.08 & 7.26 & 7.23 & 6.91 & 8.82 & 12.45 & 16.08 \\
\hline $\begin{array}{l}\text { Manufacture of } \\
\text { automobiles and other } \\
\text { motor vehicles }\end{array}$ & 7.37 & 6.92 & 7.78 & 7.26 & 7.06 & 6.63 & 6.63 & 5.58 & 4.87 \\
\hline Total & 40.1 & 40.9 & 43.0 & 41.8 & 40.3 & 40.9 & 42.1 & 43.4 & 45.6 \\
\hline
\end{tabular}

Source: GSO (2014) 
The operations of firms involved in processing/manufacturing industries are characterized as follows:

\section{a. Electrical/electronic appliances}

There has been a huge imbalance in SIs for electrical/electronic appliances; consumer electronic products make up approximately $80 \%$, in contrast to a lack of specially-designed electronic products ( $\mathrm{Vu}, 2014)$. Domestic enterprises engage mainly in processing processes to merely design basic components mostly contigent upon available templates or other foreign ones; coordination among enterprises could be well noted for product supply. In addition, only a few FDI enterprises have had success in producing printed circuit boards and industrial electrical/electronic equipment according to orders and stock holding. Table 5 presents localization ratios with respect to SIs' products for electrical/electronic appliances.

\section{Table 5}

Localization ratios with respect to SIs' products for electrical/electronic appliances

\begin{tabular}{|c|c|c|}
\hline Category & In manufacture, typified by & $\begin{array}{l}\text { Estimated localization } \\
\text { ratios as of } 2014\end{array}$ \\
\hline Audio-visual equipment & $\begin{array}{l}\text { Wafers, sensors, printed circuits, } \\
\text { information technology equipment, signal } \\
\text { reception equipment, camera components }\end{array}$ & $6-10 \%$ \\
\hline $\begin{array}{l}\text { Static/Non-rotary } \\
\text { electrical equipment }\end{array}$ & $\begin{array}{l}\text { Whole core (laminated punched electrical } \\
\text { steel sheet, wires) and peripheral } \\
\text { components such as frames, racks, etc. }\end{array}$ & $60-65 \%$ \\
\hline $\begin{array}{l}\text { Rotary electrical } \\
\text { equipment }\end{array}$ & $\begin{array}{l}\text { Stators, rotors, and other peripheral } \\
\text { components such as fins, cooling fins, etc. }\end{array}$ & $55-60 \%$ \\
\hline Others & $\begin{array}{l}\text { Metal and plastic parts such as support } \\
\text { trays, bases, packaging, and other } \\
\text { products facilitated by domestic } \\
\text { accessories including wires, switchboards, } \\
\text { switches, etc. }\end{array}$ & $50-55 \%$ \\
\hline
\end{tabular}

Source: Survey conducted by the authors at some typical enterprises in SIs for electrical/electronic appliances on the basis of the 2014 SI development project in HCMC. 


\section{b. Mechanical manufacturing}

The chief material used in mechanical manufacturing is prefabricated metal. Stable supply of domestic steel well supports the industry, yet the biggest problem lies in steel for mold making; this, if resolved, will definitely ensure the healthy development of supporting manufacturing (Chu, 2014). SI products are mainly functioned in the household mechanical domain, replacing equipment in imported synchronous lines. Overall, weaknesses remain in such stages as surface treatment, billet creation, and manufacture of synchronous and automatic equipment. The results of the survey further demonstrate localization ratios with respect to SIs' products for mechanical manufacturing (Table 6).

\section{Table 6}

Localization ratios with respect to SIs' products for mechanical manufacturing

Category In manufacture, typified by

Metal structures, water tanks

Molds and metal equipment

Engines, turbines, pumps, compressors

Stoves, ovens

Common and specialized

industrial machinery
Steel sheets, steel pipes, steel shapes

$75-80 \%$

Molds and metal equipment (current

biggest problem: steel for mold making)

$55-60 \%$

Components for small gas engines and

diesel engines in agricultural

manufacture

Cast iron pump/compressor bodies and

$32-35 \%$

other kinds of components for

assembly and/or repair such as piston

rings, O-rings, connecting rods, etc.

Grates, filaments, conveyors

$42-45 \%$

Mainly frames

$13-15 \%$ 
Category

In manufacture, typified by

Estimated localization ratios as of 2014

\begin{tabular}{lll}
\hline & $\begin{array}{l}\text { Semi-finished/surface treatment } \\
\text { praft machines and other }\end{array}$ & products and general standardized \\
mechanical products & parts such as bolts, nuts, washers, & $60-63 \%$ \\
& latches, balls, cogwheels, etc. & \\
\hline
\end{tabular}

Source: Survey conducted by the authors at some typical enterprises in SIs' for mechanical manufacturing on the basis of the 2014 SI development project in HCMC.

\section{c. Manufacture/Assembling of automobiles and motor vehicles}

The results of the survey at typical enterprises in SIs for manufacture/assembling of automobiles and motor vehicles reveal that these enterprises by far are involved in the processes of manufacturing electrophoresis paint, electrostatic paint, tires, electric wiring, air bags, inner packing materials, plastic parts, inner tubes, brake pads, seats and beds, lamp shades, oil filters, glass, leaf springs, A/C systems, semiconductor ICs, hydraulic jack control panels, etc. Imported accessories comprise engines, chassis, powertrains, control systems, carburetors, etc. The localization ratios with respect to SIs' products for manufacture/assembling of automobiles and motor vehicles are presented in Table 7 below.

\section{Table 7}

Localization ratios with respect to SIs' products for manufacture/assembling of automobiles and motor vehicles

\begin{tabular}{|c|c|c|}
\hline Category & In manufacture, typified by & $\begin{array}{c}\text { Estimated } \\
\text { localization ratios as } \\
\text { of } 2014\end{array}$ \\
\hline Private vehicles & $\begin{array}{l}\text { Electrophoresis paint, frames, tires, electrostatic } \\
\text { paint/power coating after assembling completion; } \\
\text { supporting products such as electric wiring, air bags, } \\
\text { hydraulic jack control panels, semiconductor ICs, } \\
\text { and oil filters supplied by a few SI (mainly FDI) } \\
\text { enterprises; tires for small cars recently available in } \\
\text { the marketplace. }\end{array}$ & $8.5 \%$ \\
\hline Commercial & $\begin{array}{l}\text { Bodies (coachwork), cushioned seats, brake pads, } \\
\text { inner tubes, floor mats, pedals, interior plastic parts, }\end{array}$ & $20 \%$ \\
\hline
\end{tabular}




\begin{tabular}{lll}
\hline \multicolumn{1}{c}{ Category } & \multicolumn{1}{c}{ In manufacture, typified by } & $\begin{array}{c}\text { Estimated } \\
\text { localization ratios as } \\
\text { of } 2014\end{array}$ \\
\hline passenger vehicles & door handles, seats and beds, electric wiring \\
& $\begin{array}{l}\text { Bodies (coachwork), chassis, heavy load tires, leaf } \\
\text { springs, oil filters, lamp shades, brake pads, glass, } \\
\text { Trucks and other } \\
\text { specialized vehicles } \\
\text { floor mats, all of which have been researched and } \\
\text { produced }\end{array}$ & $15.5 \%$ \\
\hline
\end{tabular}

Source: Survey conducted by the authors at some typical enterprises in SIs for manufacture/assembling of automobiles and motor vehicles on the basis of the 2014 SI development project in HCMC.

\section{d. Textile and garment}

There is a wide diversity of SIs' products for textile and garment, yet outsourcing in the textile/garment industries becomes overwhelmingly dominant, and raw materials are thus ordered and supplied by customers (Dinh et al., 2014). Although the Government has directed the industry to transform from outsourcing into mastering its design procedures in recent years, the orientation has yet to be effective due to Vietnam's enterprises' incompetence in designing the products, which are only domestically consumed with low market capacity. Meanwhile, building a successful Vietnamese brand of exported fashion products faces great hardship as international high-quality fashion brands have already been in existence together with remarkable product innovations.

The results achieved from the survey at some typical enterprises in SIs for textile and garment reveal supporting products mainly in the processing stages of low added value, including buttons, interlinings, foam bonds, cotton linings, plastic fasteners, grommets, blankets and throws, cushions, threads, zippers, glue, elastic band, and adhesive tape. Products in the stages of high added value such as fibers and chemicals - auxiliaries required in dyeing, printing, and finishing-need importing. The localization ratios with respect to SIs' products for textile and garment are presented in Table 8 below. 


\section{Table 8}

Localization ratios with respect to SIs' products for textile and garment

\begin{tabular}{llc}
\hline \multicolumn{1}{c}{ Category } & \multicolumn{1}{c}{ In manufacture, typified by } & $\begin{array}{c}\text { Estimated localization } \\
\text { ratios as of 2014 }\end{array}$ \\
\hline Fabrics, threads, & $\begin{array}{l}\text { Woven/Nonwoven fabrics, nets } \\
\text { nets, braids }\end{array}$ & $\begin{array}{l}\text { account for approximately 98\% and 2\% } \\
\text { respectively) }\end{array}$ \\
Bdult's clothing & $\begin{array}{l}\text { Backings (interlinings, foam bonds, cotton linings) } \\
\text { successfully provided by domestic enterprises but } \\
\text { applied to low and middle quality products; } \\
\text { supplies for exported ones requiring import. }\end{array}$ & mainly imported \\
\hline Children's clothing & Materials fairly well provided domestically & $45 \%$ \\
\hline
\end{tabular}

Source: Survey conducted by the authors at some typical enterprises in SIs for textile and garment on the basis of the 2014 SI development project in HCMC.

\section{e. Leather and footwear}

The main activity of Vietnam's SIs for leather and footwear features outsourcing for export; thus, the manufacture of and/or material supply to the industry relies heavily on foreign partners (Dinh et al., 2014), mostly including China, Taiwan, and Korea. The results achieved from the typical leather/foorwear enterprise survey reflect such shortcomings as limited supply of leather, raw hides and skins, and synthetic/artificial leather, all of which have not satisfied domestic demands for manufacture. The localization ratios with respect to SIs' products for leather and footwear are presented in Table 9 below. 


\section{Table 9}

Localization ratios with respect to SIs' products for leather and footwear

Category

Adults' leather/pleather (artificial/faux leather)

shoes/sandals

Children's leather/pleather (artificial/faux leather)

shoes/sandals

Fabric shoes/sandals

Sports shoes

Other leather/pleather products
Estimated localization ratios as of 2014

$37-40 \%$

$38-40 \%$

40-43\%

$39-42 \%$

$38-40 \%$

Source: Survey conducted by the authors at some typical enterprises in SIs for leather and footwear on the basis of the 2014 SI development project in HCMC.

The analyses show that Vietnam has gained certain advantages in the exploitation of raw materials. Still, due to limited refining capability, the export largely serves to accentuate semi-finished or raw materials, whereas refined materials and auxiliary products for the manufacture/assembling of the finished ones are to be imported in vast amounts. SIs' weaknesses do restrain sustainable development of the whole industry, to wit: SIs for mechanical appliances primarily give support to household mechanical domain toward repairing/replacing equipment in imported synchronous lines; SIs for manufacture of automobiles and other motor vehicles reflect moderate involvement and have yet to establish closer connection with the value chains of activities of automobile industry; SIs for electronic/electrical appliances have signified their lowlevel operations; and SIs for texture/garment and leather/footwear rely heavily on imported sources as manufacture has mainly based on outsourcing.

The most serious drawback of Vietnam's SIs is the lack of industrial machine tools, the majority of which need to be imported. The reason is that businesses are still weak in their research and product design and thus could not determine domestic demands for auxiliary products (most of Vietnam's finished products comply with design specifications provided by external customers). Furthermore, the process of industrialization has created higher and higher demands for SIs' products, and the fact that these are not satisfied by domestic manufacturers whereas current pitfalls of imports persist would lead to greater reliance upon overseas marketplace and less 
improvement in both competitiveness and investment efficiency. The SIs' weaknesses, otherwise speaking, in long terms are accounting for the poor competitiveness of Vietnam's industries. Overall, the realities of the country's SIs are depicted in Figure 3 below.

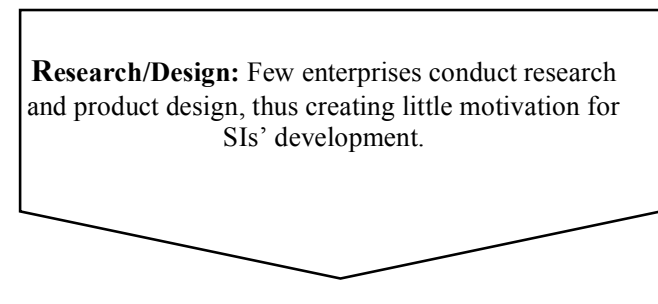

Supportive activities: SIs

Machine tool: None have yet to be sucessfully manufactured.

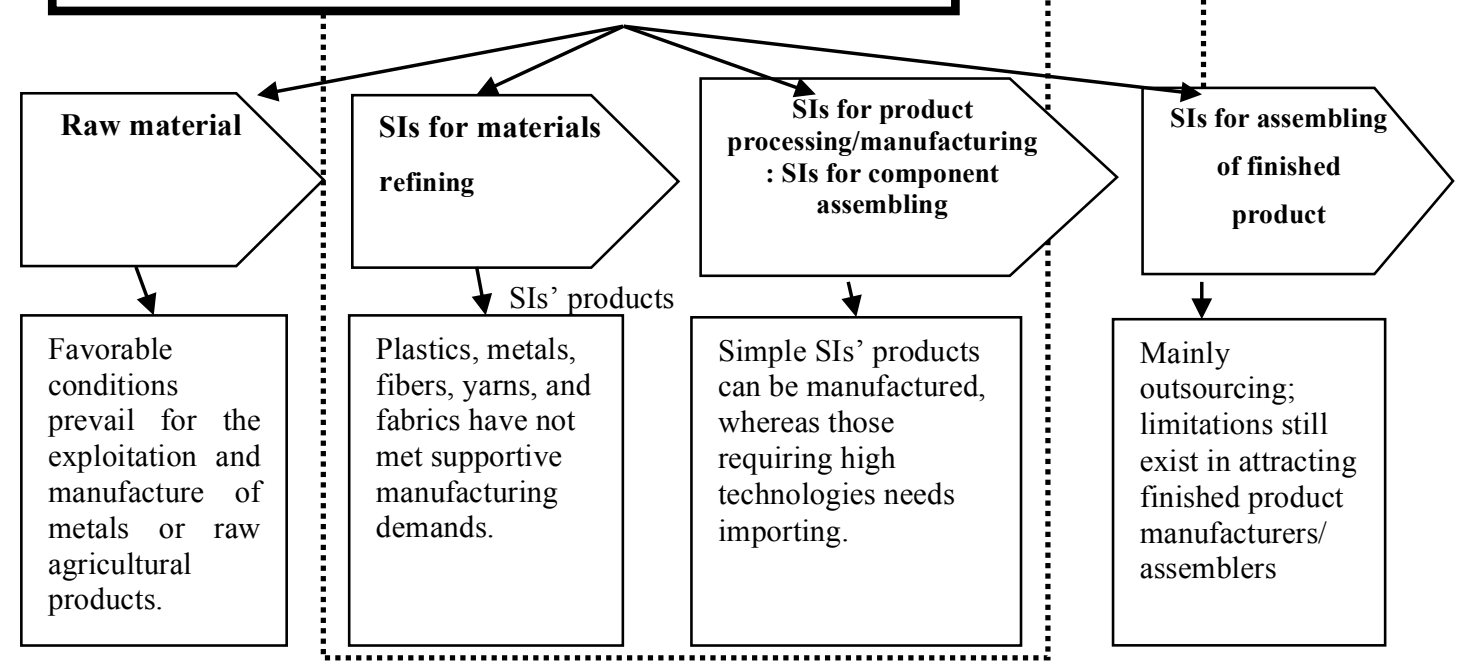

Figure 3. Current state of Vietnam's SIs

Source: Authors' summary based on the above analyses of realities 


\section{Analyses of barriers and limitations of SIs' development policy}

\subsection{Barriers to SIs' development}

Market-related barriers: Demands for the manufacture of SIs' products have not been directed to domestic firms. Since outsourcing production method (involving SIs for texture/garment and leather/footwear, for instance) has been maintained for too long within finished product manufacturers, the SIs' product supply is to be designated by customers, thereby creating barriers to suppliers' entry. On the other hand, the number of FDI enterprises, regarding the sectors of high added value, becomes dominant; domestic backup supply resources have not been oriented as local enterprises have yet to meet the requirements for quantities and/or technical qualities as well as trade commitments. Moreover, connection between local and FDI finished product manufacturers has been found notably lacking.

Technological barriers: Technologies in SIs' manufacturing processes are in slow development, whereas a large majority of machine tools in the country require imports, especially in material production. Moreover, SIs' production trait requires that it be well integrated with the manufacture and assembling of finished products, so SIs enterprises should be closely associated with manufacturers of such kind. Nevertheless, there has been a tenuous link between technology research agencies, such as technological institutes and universities, and SIs enterprises in Vietnam in the course of technology transfer, by reason of legally binding mechanisms which are absent in the policy on scientific and technological development.

Barriers in attracting finished product manufacturers: The weaknesses as revealed by SIs have led to weak competitiveness of domestic key industries and difficulties in attracting FDI enterprises as well as heavy dependence on imports. Failure to captivate the manufactures of finished products would re-erect the market-related barriers to domestic firms. 


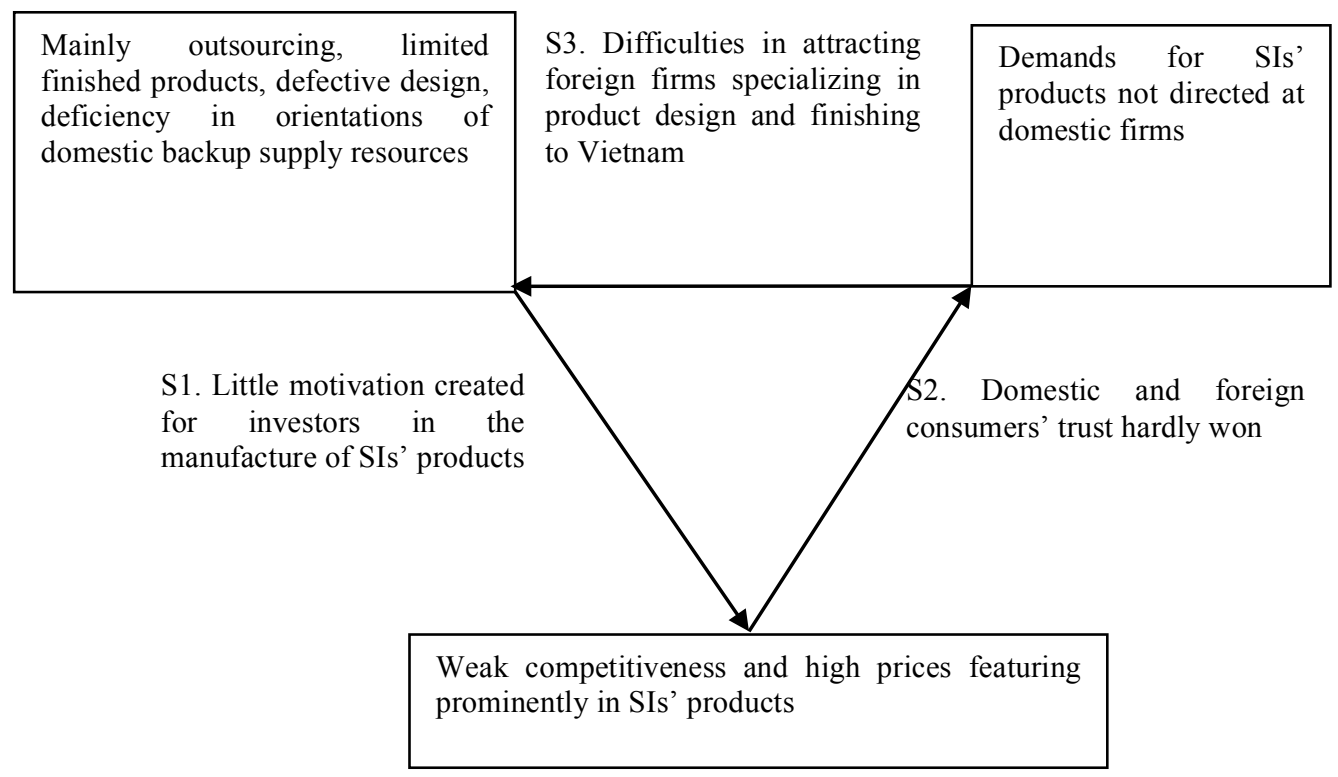

Figure 4. Barriers to SIs' development at a glance

Source: Authors' summary based on the above analyses of barriers

\subsection{Vicious circle of SIs' development in Vietnam}

A vast majority of Vietnamese enterprises are small- and medium-sized, having been blocked in a vicious circle caused by the barriers as analyzed earlier, especially when SIs' development is referred to. Up to 2013 these enterprises accounted for $95.81 \%$ of the number of Vietnam's enterprises, and their workforce made up $42.26 \%$ of that of the whole country's industry sector. Still, little contribution has been made in terms of revenue, profitability, and state budget payment. Return on total assets of SMEs, as of 2013 , reached $1.8 \%$, whereas this figure for all enterprises in the industry sector was $6.9 \%$ on average (Enterprise Development Agency, 2014).

\section{Table 10}

Proportion of SMEs and their contribution in the whole industry sector

\begin{tabular}{lccc}
\multicolumn{1}{c}{ Year } & 2011 & 2012 & 2013 \\
\hline Number of enterprises & $95.53 \%$ & $96.02 \%$ & $95.81 \%$ \\
Workforce & $44.98 \%$ & $44.92 \%$ & $42.26 \%$
\end{tabular}




\begin{tabular}{lccc}
\hline \multicolumn{1}{c}{ Year } & 2011 & 2012 & 2013 \\
\hline Revenue & $20.77 \%$ & $22.44 \%$ & $21.36 \%$ \\
Profitability & $-6.97 \%$ & $2.22 \%$ & $6.68 \%$ \\
State budget payment & $10.99 \%$ & $14.65 \%$ & $9.78 \%$ \\
\hline
\end{tabular}

Source: GSO (2014)

The SME economic sector is vulnerable and mostly active in SIs where marketrelated barriers exist along the other addressed limits of technology and capacity to produce finished products, so is often trapped in a vicious circle of low competitiveness. This circle arises from capital constraints, causing obstacles to SMEs' access to credit (due to small collateral) for investment in technology innovations. As a result, poor quality products and high prices are offered, resulting in low economic efficiency and difficulties in capital accumulation and access to the value chains in product-finishing stages. SMEs, to survive and grow, must therefore achieve a breakthrough in eliminating one of the "bottlenecks" of the cycle, above all, the technological aspects. However, little success will be notched up if these are solely dependent on their intrinsic efforts. Hence, assistance from policy mechanisms should also be required.

\subsection{Limitations of existing policies on SIs}

There have so far been multiple policies in Vietnam aiming to support SMEs scattered among the offices and governed by a number of regulations, decrees, and legal codes, to wit: Decision No. 12/2011/QD-TTg dated February 24, 2011 on policies on development of a few SIs; Decision No. 1556/2012/QD-TTg dated October 17, 2012 on approving the Master Plan on helping SMEs to develop in SIs; and Circular No. 96/2011/TT-BTC dated July 4, 2011, guiding the implementation of financial policy stipulated in Decision No. 12/2011/QD-TTg dated February 24, 2011. Apart from these, there are others related to SIs' development such as those on downstream automotive industries and programs of key mechanical products (Truong, 2014).

The stated policies on SIs' development have manifested themselves from the following aspects: capital/credit support and other different schemes to support training and development of human resources; market/technological support and support for 
premises development (Department of Industrial Economy, 2014) (Figure 5). Generally, these are adequate, but limited effects have reflected due to: (i) too broad scope of incentives, integrated in various legal documents, highlighting focus on incentives but little supportive assistance and complicated procedures; (ii) lack of managerial hub, overlapped management and operation, restrictions on preferential procedure guidance; (iii) lack of action programs/projects on the stated support; (iv) neglecting to foster domestic enterprises' business transformation into self-employed design and material manufacturing development; and (v) aiming to attract enterprises that employ simple techonologies and low-skilled workforce instead of those specializing in product design and finishing stages.

\begin{tabular}{l}
\hline Capital support: \\
Development programs have \\
not focused on SIs, hardly \\
involving SMEs. \\
\hline
\end{tabular}

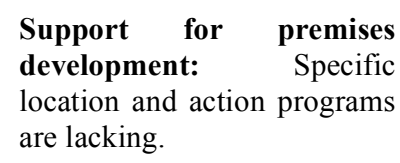

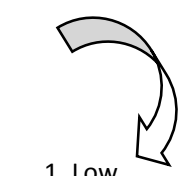

1. Low economic efficiency, arduous accumulation of capital

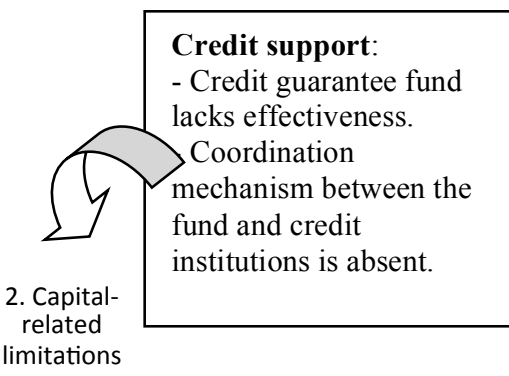

limitations
5. Low quality products, high

prices, low

competitiveness

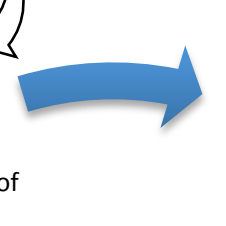

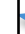

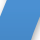

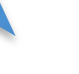




\section{Orientations and solutions to development of Vietnam's SIs}

\subsection{Orientations toward SIs' development}

The emprical results indicate that shortcomings of Vietnam's SIs spread across raw materials, technologies, marketplace, business practices, and inefficient State's policies, whereby the major weakness lies in technological factors. Thus, the orientations toward SIs' development must take account of specific domains to be priorly tackled and remove existing barriers, including the following:

- Firstly, regarding types of SIs, attract business investment in and/or enhance manufacturing capacity of specific SIs, for mechanical appliances, plastics and rubber, electrical/electronic equipment, textile and garment, and leather and footwear (mechanical metals, plastics, and rubber are input materials provided for various types of SIs, whereas textile and garment, and leather and footwear traditionally and substantially contributes to increasing Vietnam's export turnover).

- Secondly, regarding coordination in manufacturing, drive enterprises to the production and assembly of finished products using domestically supplied supporting materials; as such, a system of profitable enough businesses may be formed to be involved in the production and supply of SI products to certain industries requiring prior development.

- Thirdly, regarding technology transfer supports, gradually establish favorable environments via production cooperation between FDI and domestic enterprises for rapid mastery of technological advances; the main aim is to set up and promote narrow-specialized technological institutions associated with university colleges, which maintains a harmonious school-business relation in research and technology transfer.

- Fourthly, regarding the integration into global value chains, support enterprises operating in SIs in their meeting requirements imposed by assembling enterprises, especially multinational corporations; market orientations should be defined not only nationally but also internationally. 
- Fifthly, regarding improvement in monitoring systems, encourage a subtle shift from outsourcing to self-design production practices.

- Lastly, regarding attractive business environment aimed for the SIs enterprises, stimulate a higher demand for supports (high market capacity) and yet more convenience in access to credit and/or technologies; as attested to by the research results, the settings of Vietnam's SIs cannot prove to be appealing because of restrictions on domestic enterprises' capability to approach the marketplace, capital shortages, and difficulties in access to technologies and production premises.

\subsection{Solutions to SIs' development}

In order to attain the aforementioned goals, the following solutions should be considered:

Firstly, consolidate state organizations in their roles of supervising all SIs-related administrative activities from central to local levels and providing enterprises with capital/credit/technological support by establishing:

(i) SIs Development Centers that control different activities such as policy advice, counseling, procedural support for preferential access, market support, investment promotion, coordination in applied research and technology transfer, human resources training, and implementation of joint production programs;

(ii) SIs Development Funds to perform the lending/financial assistance/credit guarantee functions in SIs; and

(iii) Specialized Technological Institutes on the basis of selecting some typical colleges with available facilities and/or laboratories qualified for being upgraded to this kind of institutes that will be working in association with businesses, whose investment in turn should be stimulated by sound mechanisms, thereby enabling themselves to order research into new products in these institutes. 


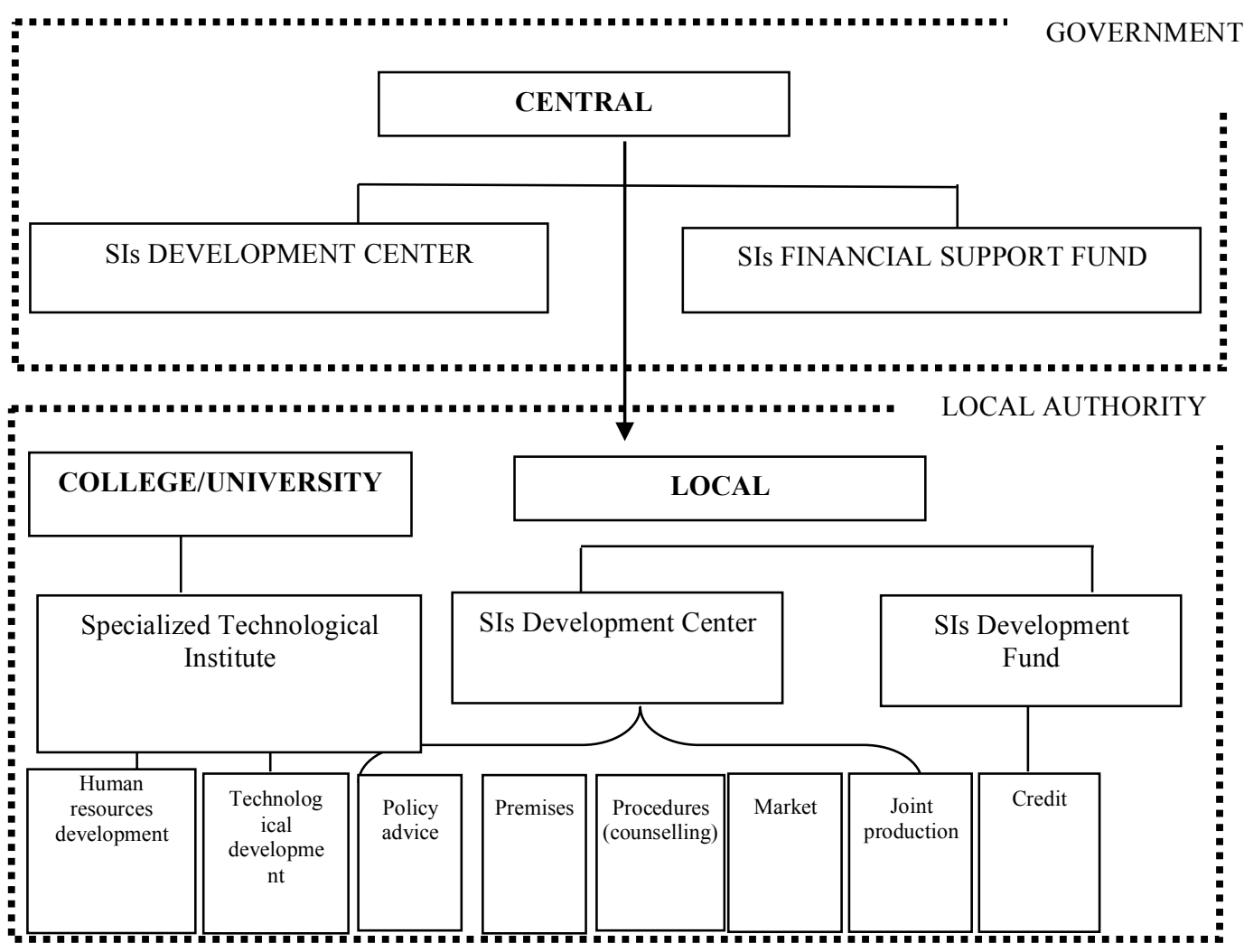

Figure 6. Proposed organizational structure for development of Vietnam's SIs

Secondly, regarding administrative procedures and counselling for preferential/supportive policies, SIs Development Center can be deemed "one-stop shop", receiving and handling those framed for SIs firms per technologies, premises, capital, credit, marketplace, etc. in a transparent, systematic, and highly responsible manner, and also every regulation as well as procedure for supportive activities needs to be electronically published.

Thirdly, joint production and participation in global value chains require that a comprehensive database be created of SIs enterprises, mostly FDI and domestic ones. It is also important to favor FDI firms associated with domestic enterprises in material production and supply of SIs' products. Additionally, since the value chains of the industries are not simply restricted to local/national level but cover interdisciplinary, interregional, and transnational perspectives, SI-related business programs in which 
cooperation is highlighted between domestic cities/provinces and foreign countries are to be encouraged.

Fourthly, the functions of Specialized Technological Institutes are to help carry out research and technology transfer, supporting enterprises by: (i) initially examining different kinds of technologies applied to prioritized products (high demands) to aid firms' investment; and (ii) in a long run plan on research into new technologies and their transfer to other sectors. SIs' technological development mechanisms need to be adopted toward funding scientific projects implemented by the involved firms. SIs Development Centers may function as guidance counselors to facilitate firms' access to the Specialized Technological Institutes for further technology transfer guidelines.

Finally, premises in existing industrial parks should be replanned to save land for SIs enterprises, particularly by driving infrastructure investors toward the construction of small-area multi-story manufacturing plants, subsequently rented to SMEs at favorable charges (infrastructure investment costs and loan rates subsidized by the Government together with the lease price of premises imposed on the infrastructure investors), and narrow specialized SIs clusters, relocated in the industrial parks with available vacant space

\section{References}

Chu, D. K. (2014). Steel industry in association with supporting industries (in Vietnamese). In Realities of and orientations and solutions to development of Vietnam's supporting industries. Paper presented at the Proceedings of Scientifc Conference of Central Economic Committee (pp. 191-202). Ho Chi Minh City, Vietnam: UEH Publishing House.

Department of Industrial Economy. (2014). Realities of and orientations, and solutions to the development of Vietnam's supporting industries (in Vietnamese). In Realities of and orientations and solutions to development of Vietnam's supporting industries. Paper presented at the Proceedings of Scientifc Conference of Central Economic Committee (pp. 105-120). Ho Chi Minh City, Vietnam: UEH Publishing House.

Dinh, T. H., Mishra, D., Le, D. B., Pham, M. D., \& Pham, T. T. H. (2014). Light industry development in Vietnam. Washington, DC: The World Bank.

Eiamkanitchat, R. (1999). The role of small and medium supporting industries in Japan and Thailand. Chiba Prefecture, Japan: APEC Study Center, Institute of Developing Economies.

Enterprise Development Agency. (2014). White book: Small and medium enterprises in Vietnam (in Vietnamese). Hanoi, Vietnam: Statistical Publishing House. 
General Department of Vietnam Customs. (2014). An overview of Vietnam's import and export of goods in 2014 (in Vietnamese). Retrieved December 22, 2014 from http://www.customs.gov.vn

General Statistics Office of Vietnam. (2014). Statistical Handbook of Vietnam. Hanoi, Vietnam: Statistical Publishing House.

Huynh, T. D. (2014). Removing barriers to development of supporting industries (in Vietnamese). In Realities of and orientations and solutions to development of Vietnam's supporting industries. Paper presented at the Proceedings of Scientifc Conference of Central Economic Committee (pp. 73-86). Ho Chi Minh City, Vietnam: UEH Publishing House.

Nguyen, T. H., \& Huynh, T. D. (2012). Policies on replanning and promoting development of Vietnam's supporting industries (in Vietnamese). Journal of Economic Development, No. 263, 2-10.

Takahashi, Y. (2014). Japanese small and medium enterprises until 1990s and Thai small and medium enterprises at present: What and how do the Vietnamese learn from both countries? In.Management and Business. Paper presented at the Proceedings of Scientifc Conference on Management and Business (COMB) (pp. 81-96). Danang City, Vietnam: University of Danang.

Truong, T. H. (2014). Policies on development of supporting industries (in Vietnamese). In Realities of and orientations and solutions to development of Vietnam's supporting industries. Paper presented at the Proceedings of Scientifc Conference of Central Economic Committee. Ho Chi Minh City, Vietnam: UEH Publishing House.

Vietnam Electronic Industries Association. (2014). Survey on Vietnam's electronic enterprises (in Vietnamese). Unpulished manuscript.

Vietnamese Government. (2011a). Circular No. 96/2011/TT-BTC of July, 4, 2011 guiding the financial policies specified in the Prune Minister's Decision No. 12/2011/QD-TTg of February 24, 2011,on policies on development of a number of supporting industries (in Vietnamese). Retrieved from http://thuvienphapluat.vn/van-ban/Doanh-nghiep/Thong-tu-96-2011-TT-BTC-huong-dan-chinhsach-tai-chinh-126337.aspx

Vietnamese Government. (2011b). Decision No. 12/2011/QD-TTg dated February 24, 2011, on policies on development of a number of supporting industries (in Vietnamese). Retrieved from http:/thuvienphapluat.vn/van-ban/Doanh-nghiep/Quyet-dinh-12-2011-QD-TTg-chinh-sach-phattrien-nganh-cong-nghiep-ho-tro-119295.aspx

Vietnamese Government. (2012). Decision No. 1556/2012/QD-TTg dated October 17, 2012, on approving the Master Plan on helping SMEs to develop in supporting industries (in Vietnamese). Retrieved from http://thuvienphapluat.vn/van-ban/Doanh-nghiep/Quyet-dinh-1556-QD-TTg-nam2012-phe-duyet-De-an-Tro-giup-phat-trien-doanh-nghiep-149737.aspx

$\mathrm{Vu}, \mathrm{T}$. T. H. (2014). Realities of and solutions to improving the competitiveness of Vietnam's electronic industry after WTO accession (in Vietnamese). Retrieved from http://doc.edu.vn/tai-lieu/chuyen-dethuc-trang-va-giai-phap-nang-cao-suc-canh-tranh-nganh-cong-nghiep-dien-tu-viet-nam-sau-khi-gianhap-wto-29643 